\title{
Chemical Composition and Anti-Inflammatory Activity of the Hydrodistillate from Mariscus pedunculatus
}

\author{
Antonio C. Siani ${ }^{a *}$, Ana M. P. Silva ${ }^{a}$, Marcos J. Nakamura ${ }^{a}$, Márcia V. De Carvalho ${ }^{a}$, \\ Maria G. M. O. Henriques ${ }^{a}$, Mônica F. S. Ramos ${ }^{a, b}$ and Carlos R. Kaiser ${ }^{c}$ \\ ${ }^{a}$ Laboratório de Química de Produtos Naturais e Farmacologia Aplicada, Far-Manguinhos, FIOCRUZ, 21041-250, \\ Rio de Janeiro - RJ, Brazil \\ ${ }^{\mathrm{b}}$ Departamento de Medicamentos, Faculdade de Farmácia, Universidade Federal do Rio de Janeiro, CCS, Cidade \\ Universitária, 21910-240, Rio de Janeiro - RJ, Brazil \\ ${ }^{\mathrm{c}}$ Departamento de Química Orgânica, Instituto de Química, Universidade Federal do Rio de Janeiro, 21949-970, \\ Rio de Janeiro - RJ, Brazil
}

\begin{abstract}
Os rizomas de Mariscus pedunculatus, quando submetidos à hidrodestilação, forneceram uma mistura do diidrobenzofurano remirol e do benzopirano iso-evodionol, na proporção de 5.7:1. Estas substâncias foram separadas e purificadas por intermédio de sucessivas cromatografias de camada delgada preparativa. As estruturas foram confirmadas por métodos espectroscópicos, incluindo técnicas bidimensionais de RMN, e pelo produto de hidrogenação, no caso do remirol. Entre as substâncias voláteis, foram identificados traços de outros oito sesquiterpenos por CGEM associada aos cálculos de índice de retenção. O hidrodestilado bruto, assim como as substâncias purificadas foram testadas quanto à atividade antiinflamatória, no modelo de pleurisia induzida em camundongos por lipopolissacarídeo (LPS, $12,5 \mathrm{ng} / \mathrm{cavidade}$ ). Tanto o extrato bruto quanto o remirol puro (100 e $200 \mathrm{mg} \mathrm{kg}^{-1}$, via oral) demonstraram uma capacidade dose-dependente de inibir o acúmulo de neutrófilos e eosinófilos na cavidade pleural dos animais. O iso-evodionol não apresentou efeito antiinflamatório.
\end{abstract}

A mixture of the benzofuran remirol and the benzopyran isoevodionol (5.7:1) was extracted by hydrodistillation from rhizomes of Mariscus pedunculatus. They were purified by successive thin layer chromatography. Their structure elucidation were confirmed by 2D-NMR experiments. The structure of remirol was also confirmed by its hydrogenation product. Crude distillate and the pure compounds were screened for anti-inflammatory activity by the use of the mouse pleurisy model induced by lipopolysaccharide (LPS, $12.5 \mathrm{ng} /$ cavity). Both the mixture and remirol showed a dosedependent (100 and $200 \mathrm{mg} \mathrm{kg}^{-1}$ p.o.) capacity to inhibit neutrophil and eosinophil accumulation in the mouse pleural cavity. In contrast, no anti-inflammatory effect was observed for iso-evodionol.

Keywords: Mariscus pedunculatus, benzofuran derivative, remirol, iso-evodionol, antiinflammatory activity

\section{Introduction}

Mariscus pedunculatus (R. Br.) T. Koyama (sin. Remirea maritima Aubl.) is a cosmopolitan tropical Cyperaceae species, with a reticulated root system, developing their rhizomes through the sand. They occur along Brazil sea-shores and in some regions of southeast they are popularly used in medicinal preparations for

* e-mail: siani@far.fiocruz.br treating diarrhea and is also commonly added as a flavour in drinks.

Chemical examination of the ether extract of the plant growing in Australia showed the presence of quinones, chromenes and isoprenoid acetogenins ${ }^{1,2}$. Isoprenoid acetogenins showed activity in bioassays as inhibitors of several microorganisms as well as toxicity to goldfish and chicks. Some of them also exhibited weak activity against leukemia or showed insecticidal and repellent action ${ }^{3}$.

The chemical composition of the hydrodistillate of the rhizomes and roots from Brazilian specimens of 
Mariscus pedunculatus was investigated. Hydrodistillation was chosen in order to facilitate the initial separation of different classes of compounds since several chromenes and benzofurans having a tremetone-like structure are volatile $^{3}$. These form a group of biogenetically related metabolites whose occurrence and structural variations have been suggested to represent useful taxonomic characters at the tribal and generic levels in some botanical family, as the case of Asteraceae ${ }^{3}$. In the Cyperaceae, these phenolic ketones are considered as biogenetic precursors of the insect antifeedant cyperaquinones ${ }^{4,5}$.

From the pharmacological point of view, substituted acetophenones are reported to possess a marked antiasthmatic effect in guinea pigs challenged by PAF or ovalbumin $^{6,7}$. This results encouraged us to investigate the anti-inflammatory activity of the crude steam distillate as well as the pure compounds from $M$. pedunculatus rhizomes.

\section{Results and Discussion}

Steam distillation of fresh $M$. pedunculatus rhizomes and roots afforded $0.14 \%$ of a mixture of remirol (4hydroxy-6-methoxytremetone) 1 and isoevodionol (6acetyl-5-hydroxy-7-methoxy-2,2-dimethyl-3-chromene) 3 in the proportion of $5.7: 1$, as indicated by gas chromatography and NMR experiments. Traces of sesquiterpenes were also indicated by GC/MS and their retention indexes ${ }^{8}$. Structural elucidation of compounds 1 and 3 was based on spectral analyses, including 2D NMR experiments. The absolute configuration of C-2 in purified 1 was inferred as $R$, based on the same dextrorotatory effect showed by the remirol isolated from C. nipponicus ${ }^{9}$.

Previous spectroscopic analyses of the structures of compounds $\mathbf{1}$ and 3 were made by IR, MS, ${ }^{1} \mathrm{H}$ and ${ }^{13} \mathrm{C}$ NMR techniques ${ }^{2,9,10,11}$. However, the NMR analyses lack spectrum assignments for C-3 and C-9 hydrogens in the ${ }^{1} \mathrm{H}$ spectrum and for all carbons in the ${ }^{13} \mathrm{C}$ spectrum and no support was given to the proposed substitution pattern of the aromatic ring. For this reason, the complete ${ }^{1} \mathrm{H}$ and ${ }^{13} \mathrm{C}$ NMR analyses for remirol $\mathbf{1}$ and isoevodionol $\mathbf{3}$ are now given together with those of the hydrogenated derivative dihydroremirol 2. Unambiguous chemical shifts assignments were obtained by way of 2D NMR experiments such as NOESY and gradient selected COSY, HSQC and $\mathrm{HMBC}^{12,13}$.

The NOESY experiment was primordial for some ${ }^{1} \mathrm{H}$ signal assignments and also for the definition of the substitution pattern of the aromatic ring. The NOESY spectrum for compound $\mathbf{1}$ revealed two correlations for the phenolic hydrogen (a sharp signal in the ${ }^{1} \mathrm{H}$ spectrum) with $\mathrm{H}-12$ and $\mathrm{H}-3 \mathrm{~s}$. Taking also into account that $\mathrm{H}-7$ shows correlation only with the methoxyl hydrogens $\mathrm{H}$ 13, the $\mathrm{OH}, \mathrm{COMe}$ and $\mathrm{OMe}$ groups have to be attached to C-4, C-5 and C-6 respectively. Furthermore, the methyl hydrogens $\mathrm{H}-10$ show correlation with $\mathrm{H}-9 \mathrm{c}$ as well as with $\mathrm{H}-3 \mathrm{a}$ which means, firstly, that $\mathrm{H}-10$ and $\mathrm{H}-9 \mathrm{c}$ are cis orientated to one another in the isopropenyl group, and secondly, that the isopropenyl group and $\mathrm{H}-3 \mathrm{a}$ are situated on the same side of the dihydrofurane ring. In the case of compound 2, H-3a shows NOE correlation with both methyl H-10 and H-9 and for compound 3, these two methyl groups show correlation with $\mathrm{H}-3$ and not with $\mathrm{H}-4$.

With the assignment of the ${ }^{1} \mathrm{H}$ spectrum for each of the three compounds it then becomes straightforward to assign the ${ }^{13} \mathrm{C}$ spectrum by way of $2 \mathrm{D}$ NMR ${ }^{1} \mathrm{H},{ }^{13} \mathrm{C}$-correlation experiments such as $\mathrm{HMQC}$ (which involves ${ }^{1} J_{\mathrm{CH}}$ to assign the hydrogen-bearing carbons) and HMBC (that involves ${ }^{2,3} J_{\mathrm{CH}}$ mainly to assign the non-protonated carbons). For compounds $\mathbf{1}$ and $\mathbf{2}$, the main correlations in the HMBC spectrum that establish the assignment of the five nonprotonated aromatic carbons are described: phenolic hydrogen with C-4, C-5 and C-3a; H-3s/H-3a with C-7a and C-3a; H-12 with C-5; H-13 with C-6; H-7 with C-5, $\mathrm{C}-6, \mathrm{C}-7, \mathrm{C}-7 \mathrm{a}$ and $\mathrm{C}-3 \mathrm{a}$. For compound 3 the trend is the same except that $\mathrm{H}-3$, due to the anti-periplanar arrangement, shows correlation with $\mathrm{C}-4 \mathrm{a}$ while $\mathrm{H}-4$ does not. The complete ${ }^{1} \mathrm{H}$ and ${ }^{13} \mathrm{C}$ NMR data are summarized in Table 1.

The anti-inflammatory activity was evaluated using the experimental model of mouse pleurisy induced by LPS (250 ng/cavity). The number of total leukocytes in the pleural

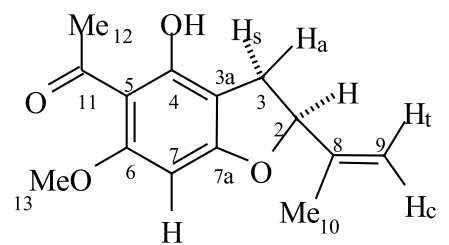

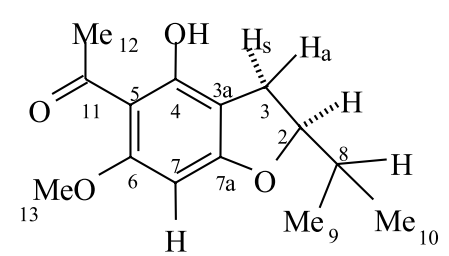

2

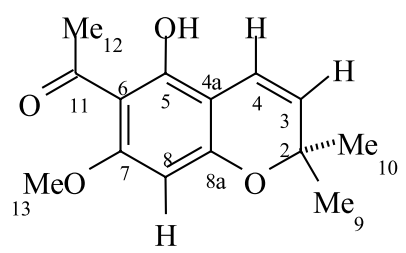

3 
Table 1. ${ }^{1} \mathrm{H}$ and ${ }^{13} \mathrm{C}$ NMR data of compounds $1-3\left(\mathrm{CDCl}_{3}, 300 \mathrm{MHz}\right)$

\begin{tabular}{|c|c|c|c|c|c|c|}
\hline \multirow[b]{2}{*}{$\mathrm{C}^{\#}$} & \multicolumn{2}{|c|}{ remirol (1) } & \multicolumn{2}{|c|}{ dihydroremirol (2) } & \multicolumn{2}{|c|}{ iso-evodionol (3) } \\
\hline & $\delta_{\mathrm{C}}$ & $\delta_{\mathrm{H}}(\mathrm{m}, J \text { in } \mathrm{Hz})^{\mathrm{a}}$ & $\delta_{\mathrm{C}}$ & $\delta_{\mathrm{H}}(\mathrm{m}, J \text { in } \mathrm{Hz})^{\mathrm{a}}$ & $\delta_{\mathrm{C}}$ & $\delta_{\mathrm{H}}(\mathrm{m}, J \text { in } \mathrm{Hz})^{\mathrm{a}}$ \\
\hline 2 & 88.3 & $5.20(\mathrm{dd}, 9.8,7.5)$ & 91.2 & $4.64(\mathrm{ddd}, 9.3,7.9,6.7)$ & 78.2 & - \\
\hline 3 & 29.9 & $\begin{array}{l}\mathrm{H}_{\mathrm{a}} 2.84(\mathrm{dd}, 15.1,7.5) \\
\mathrm{H}_{\mathrm{s}} 3.20(\mathrm{dd}, 15.1,9.8)\end{array}$ & 29.1 & $\begin{array}{l}\mathrm{H}_{\mathrm{a}} 2.81(\mathrm{dd}, 15.1,7.9) \\
\mathrm{H}_{\mathrm{s}} 3.10(\mathrm{dd}, 15.1,9.3)\end{array}$ & 125.4 & $5.45(\mathrm{~d}, 10.0)$ \\
\hline $3 a$ & 105.0 & - & 104.9 & - & - & - \\
\hline 4 & 162.0 & - & 161.3 & - & 116.0 & $6.65(\mathrm{~d}, 10.0)$ \\
\hline $4 \mathrm{a}$ & - & - & - & - & 102.7 & - \\
\hline 5 & 106.3 & - & 106.1 & - & 161.9 & - \\
\hline 6 & 164.5 & - & 164.2 & - & 105.7 & - \\
\hline 7 & 85.6 & $5.89(\mathrm{~s})$ & 85.7 & $5.93(\mathrm{~s})$ & 163.0 & - \\
\hline $7 \mathrm{a}$ & 167.0 & - & 166.9 & - & - & - \\
\hline 8 & 143.6 & - & 33.6 & $1.95(\mathrm{~m}, 7.5,6.8,6.7)$ & 91.1 & $5.88(\mathrm{~s})$ \\
\hline $8 \mathrm{a}$ & - & - & - & - & 160.2 & - \\
\hline 9 & 112.6 & $\mathrm{H}_{\mathrm{t}} 4.99(\mathrm{~s}) ; \mathrm{H}_{\mathrm{c}} 4.85(\mathrm{~s})$ & 17.8 & $0.95(\mathrm{~d}, 7.5)$ & 28.4 & $1.44(\mathrm{~s})$ \\
\hline 10 & 17.1 & $1.68(\mathrm{~s})$ & 18.1 & $1.01(\mathrm{~d}, 6.8)$ & 28.4 & $1.44(\mathrm{~s})$ \\
\hline 11 & 203.4 & - & 203.1 & - & 203.3 & - \\
\hline 12 & 33.1 & $2.52(\mathrm{~s})$ & 33.1 & $2.58(\mathrm{~s})$ & 33.1 & $2.60(\mathrm{~s})$ \\
\hline 13 & 55.9 & $3.78(\mathrm{~s})$ & 55.9 & $3.84(\mathrm{~s})$ & 55.6 & $3.85(\mathrm{~s})$ \\
\hline $\mathrm{OH}$ & - & $14.00(\mathrm{~s})$ & - & $14.08(\mathrm{~s})$ & - & $14.28(\mathrm{~s})$ \\
\hline
\end{tabular}

${ }^{\mathrm{a}}$ symbolism $\mathrm{H}_{\mathrm{a}} / \mathrm{H}_{\mathrm{s}}=$ anti/syn with respect to $\mathrm{H}-2$ and $\mathrm{H}_{\mathrm{t}} / \mathrm{H}_{\mathrm{c}}=$ trans/cis with respect to $\mathrm{H}-12$.

lavage fluid was increased at $24 \mathrm{~h}(\mathrm{P} \leq 0.05)$ after intrathoracic injection of LPS and total leukocytes, neutrophils and eosinophils were elevated. Pre-treatment with the crude hydrodistillate of Mariscus pedunculatus was ineffective at a dose of $100 \mathrm{mg} \mathrm{kg}^{-1}$ but significantly inhibited the neutrophil and eosinophil accumulation at a dose of $200 \mathrm{mg} \mathrm{kg}^{-1}\left(1.31 \pm 0.10\right.$ to $0.97 \pm 0.08 \times 10^{6} \%$ cavity for neutrophils and $0.59 \pm 0.15$ to $0.05 \pm 0.02 \times 10^{6}$ / cavity for eosinophils) (Figure1).

Pre-treatment with iso-evodionol $\left(200 \mathrm{mg} \mathrm{kg}^{-1}, p . o\right.$. $)$ was unable to inhibit total or differential cell types induced by LPS. On the other hand, pre-treatment with pure remirol reduced significantly $(p \leq 0.05)$ the eosinophil accumulation at both doses tested $\left(100 \mathrm{mg} \mathrm{kg}^{-1}: 0.42 \pm\right.$ 0.08 to $0.17 \pm 0.06 \times 10^{6} /$ cavity and $200 \mathrm{mg} \mathrm{kg}^{-1}: 0.42 \pm$ 0.08 to $0.08 \pm 0.02 \times 10^{6} /$ cavity) (Figure 2 ).

Eosinophil accumulation is an important component in allergic diseases, in parasitic and in bacterial infections and has been considered one of the responsible causes of lung tissue damage during these process. Results of the present study showed that the crude hydrodistillate of Mariscus pedunculatus or its main constituent remirol were effective in delayed inflammatory eosinophil migration, and this could be useful to control the inflammatory reaction during bacterial infections or allergic diseases.
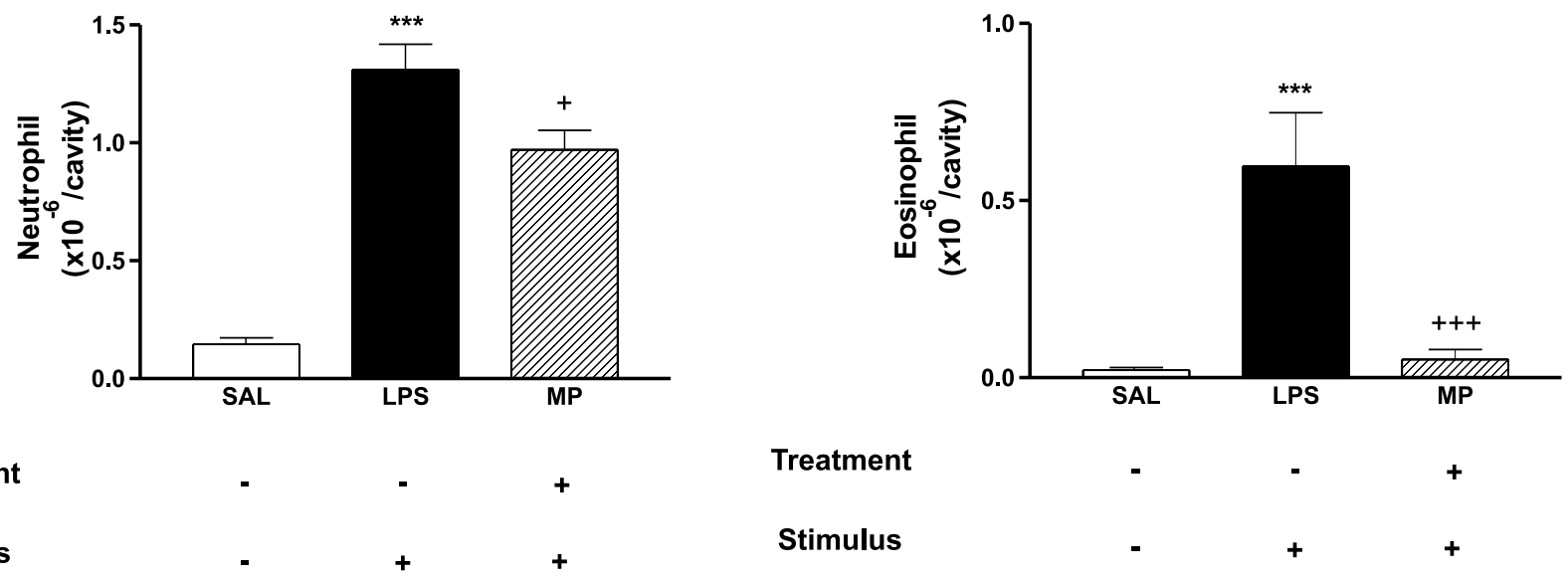

Figure 1. Effect of the crude hydrodistillate of Mariscus pedunculatus (MP) on LPS-induced neutrophil and eosinophil recruitment. $200 \mathrm{mg} \mathrm{kg}^{-1}$ (hatched columns) or vehicle (open columns) were administered p. o. $1 \mathrm{~h}$ prior to LPS ( $250 \mathrm{ng} /$ cavity). Pleural fluid was collected $24 \mathrm{~h} \mathrm{later.} \mathrm{*} \mathrm{and}{ }^{+}$ indicate $\mathrm{P} \leq 0.05$ when compared to control non-stimulated saline injected (open column) or LPS-stimulated saline-treated group (closed columns), respectively. 


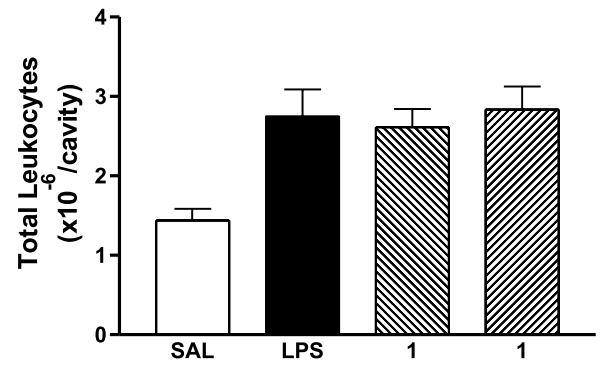

Treatment

Stimulus

Treatment

Stimulus

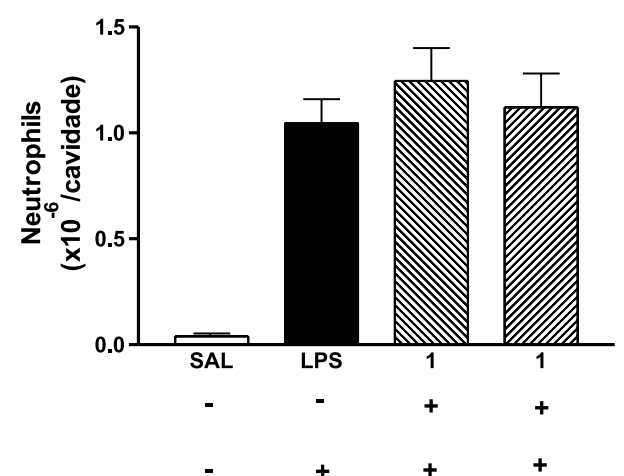

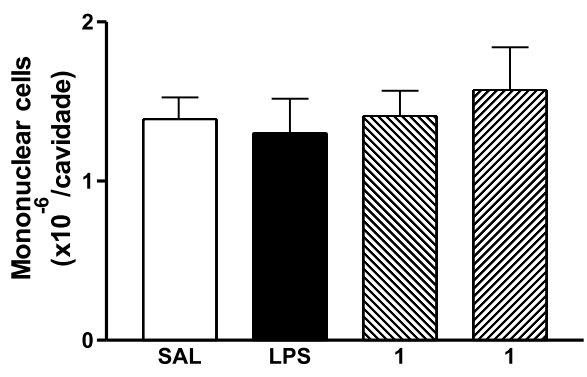

Treatment

Stimulus

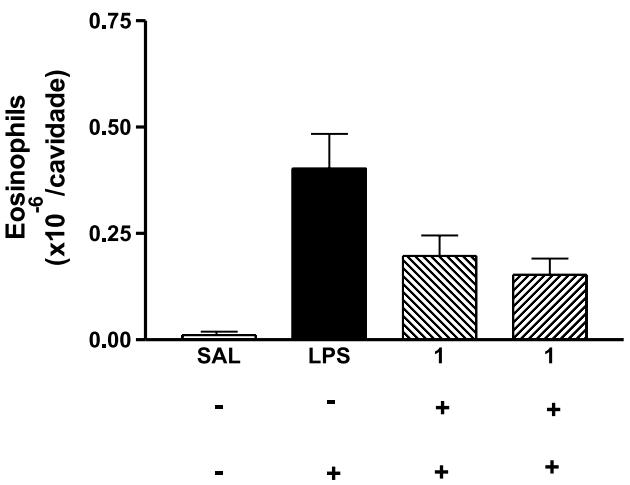

Figure 2. Effect of remirol on LPS-induced leukocyte recruitment. Remirol (1) (100 or $200 \mathrm{mg} \mathrm{kg}^{-1}$ : hatched columns) or vehicle (open columns) was administered p. o. $1 \mathrm{~h}$ prior to LPS ( $250 \mathrm{ng} /$ cavity). Pleural fluid collected $24 \mathrm{~h}$ later. $*$ or ${ }^{+}$indicate $\mathrm{P} \leq 0.05$ when compared to control non-stimulated saline injected (open columns) or LPS-stimulated saline-treated group (closed columns), respectively.

\section{Experimental}

\section{General}

Melting points were obtained in a MORPF-301 apparatus and are uncorrected. All 1D and 2D NMR spectra were recorded in $5 \mathrm{~mm}$ (o. d.) tubes in $\mathrm{CDCl}_{3}, 20 \mathrm{mg} \mathrm{mL}^{-1}$, using TMS as internal reference in a Bruker DRX300 (300 MHz for ${ }^{1} \mathrm{H}$ and $75 \mathrm{MHz}$ for ${ }^{13} \mathrm{C}$ ) spectrometer, at $300 \mathrm{~K}$. Pulse programs and processing were made using the XwinNMR 1.3/9 program, licensed by Bruker. GC/MS traces/spectra were recorded on a Hewlett-Packard computerized gas chromatograph-mass spectrometer model 6890 with a quadrupole analyzer (electron impact ionization, $70 \mathrm{eV}$ ) in a HP-5 MS capillary column (30 m x $0.32 \mathrm{~mm}$ i.d., 0.25 $\mathrm{mm}$ film thickness); carrier gas $\mathrm{He}$, detector temperature $270^{\circ} \mathrm{C}$, flow rate $0.5 \mathrm{~mL} \mathrm{~min}^{-1}$, using $\mathrm{CH}_{2} \mathrm{Cl}_{2}$ as solvent ( $\mathrm{ca}$ $2 \mathrm{mg}$ in $100 \mu \mathrm{L}$ ), $\mathrm{T}$ program $\mathrm{T}_{\mathrm{i}} 70^{\circ} \mathrm{C}, \mathrm{t}_{\mathrm{i}} 5 \mathrm{~min}, \mathrm{~T}_{\mathrm{f}} 250^{\circ} \mathrm{C}$, rate $3^{\circ} \mathrm{C} \mathrm{min}^{-1}$. Individual components were identified by comparison of mass spectra with those in the data system library (Wiley library software 59943B) and their retention indexes with reference to an n-alkane series in that temperature-programmed run $^{8}$. TLC analyses were carried out in silica gel (Merck, Kiesegel 60), and spots were visualized by UV (254 and $360 \mathrm{~nm}$ ), using acidic $O$ anisaldehyde or vanillin as coloring agent. Optical rotations were measured in a JASCO digital polarimeter model DIP370. IR spectra were taken in a Nicolet 205 spectrometer.

\section{Plant material}

Mariscus pedunculatus (R. Br.) T. Koyama was collected on the sandbank at the National Park of Jurubatiba, in the municipality of Carapebus, State of Rio de Janeiro, Brazil, and was identified by Professor Paulo C. Fevereiro of the Universidade Federal Fluminense, Niterói, RJ. The plant was collected in October 1996 and extracted few hours after collection. Voucher specimens are deposited in the Herbarium Bradnianum of the Universidade Estadual do Rio de Janeiro under No. HB 83006 and in the Herbarium of the Botanic Garden of Rio de Janeiro under No. HB 328064. 


\section{Extraction and isolation}

Rhizomes and roots (420 g) were submitted to hydrodistillation using a modified Clevenger apparatus during $8 \mathrm{~h}$, to furnish $600 \mathrm{mg}$ of an oil, denser than water, that solidified on standing at room temperature, as a reddish solid. GC-MS analysis of the crude extract showed a mixture of $1(85 \%)$ and $3(13 \%)$ (based on the relative peak areas) and traces [RI] of $\beta$-elemene [1391], $\beta$-cyperene [1399], patchoulene [1459], $\beta$-selinene [1485], $\alpha$-selinene [1493], cis-calemenene [1521], caryophyllene oxide [1582], selin-11-en-4- $\alpha$-ol [1654]; and demethoxylated $\mathbf{1}$ [1619] and 3 [1696] as suggested by their fragmentation pattern. Retention indexes of iso-evodionol and remirol were 1962 and 2046, respectively.

\section{Purification of 1 and $\mathbf{3}$}

The crude extract $(120 \mathrm{mg})$ was purified by silica gel TLC $(20 \times 20 \times 0.05 \mathrm{~cm})$, eluted three times with hexane: $\mathrm{CHCl}_{3}: \mathrm{AcOH} 7: 3: 0.1$, to afford the pure compounds $1\left(\mathrm{R}_{f} 0.35 ; 67.2 \mathrm{mg}, 56 \%\right)$ and $\mathbf{3}\left(\mathrm{R}_{f} 0.45 ; 8.4 \mathrm{mg}, 7 \%\right)$.

Remirol 1-(4-hydroxy-2-isoprenyl-6-methoxy-2,3dihydro-benzofuran-5-yl)-ethanone (1). Colorless solid, $\mathrm{mp}$ 74.0-74.8 ${ }^{\circ} \mathrm{C}\left(\mathrm{CH}_{2} \mathrm{Cl}_{2}\right)\left(\text { lit.76.5-77 }{ }^{\circ} \mathrm{C}\right)^{2} ;[\alpha]_{\mathrm{D}}{ }^{24}+65[c$ 1.0, $\mathrm{CH}_{2} \mathrm{Cl}_{2}$ ]; IR $v_{\text {max }} / \mathrm{cm}^{-1} 1640,1604,1462,1433,1137,1107$, 919, $803(\mathrm{KBr}) ;{ }^{1} \mathrm{H}$ and ${ }^{13} \mathrm{C}$ NMR see Table 1; EIMS (70 eV) $m / z 248\left(\mathrm{M}^{+}, 59 \%\right), 233$ (100), 215 (23), 205 (9), 191(13), 177 (11), 109 (13).

iso-Evodionol 1-(5-hydroxy-7-methoxy-2,2-dimethyl$2 H$-chromen-6-yl)-ethanone (3). Orange crystals, mp 124.5-125.0 ${ }^{\circ} \mathrm{C}$ (acetone-hexane) (lit. 128.5-129 ${ }^{\circ} \mathrm{C}$ ) ${ }^{2}$; IR $v_{\max } / \mathrm{cm}^{-1} 3100,2973,1621,1599,1269,1123,889(\mathrm{KBr})$; ${ }^{1} \mathrm{H}$ and ${ }^{13} \mathrm{C}$ NMR see Table 1; EIMS (70 eV) $\mathrm{m} / z 248$ $\left(\mathrm{M}^{+}, 16 \%\right), 233$ (100), 215 (29), 200 (9), 191 (4).

\section{Hydrogenation of $\mathbf{1}$}

Compound 1 (90 mg) was hydrogenated in AcOEt (10 $\mathrm{mL}$ ) over a $\mathrm{Pd} / \mathrm{C}$ catalyst, at 50 psi during $5 \mathrm{~h}$. Filtration through celite and evaporation of the solvent, followed by preparative TLC (hexane: $\mathrm{CHCl}_{3}: \mathrm{AcOH}$ 7:3:0.1), afforded $76 \mathrm{mg}(84 \%)$ of pure dihydroremirol 2.

Dihydroremirol 1-(4-hydroxy-2-isopropyl-6-methoxy2,3-dihydro-benzofuran-5-yl)-ethanone (2). Colorless crystals, mp 54.5-56.0 ${ }^{\circ} \mathrm{C}$ (hexane) (lit. 61.5-62 ${ }^{\circ} \mathrm{C}$ ) ${ }^{2}$; IR $v_{\max } / \mathrm{cm}^{-1} 1629,1602,1460,1424,1138,1106,979,860$ (KBr); ${ }^{1} \mathrm{H}$ and ${ }^{13} \mathrm{C}$ NMR see Table 1; EIMS (70 eV) $\mathrm{m} / \mathrm{z}$ $250\left(\mathrm{M}^{+}, 51 \%\right), 235$ (70), 217 (5), 207 (30), 195 (59), 179 (100), 166 (13).
Anti-inflammatory assay

Sample preparation, animals, drugs and materials

The crude distillate, pure remirol $(50 \mathrm{mg})$ or pure isoevodionol $(50 \mathrm{mg})$ were dissolved in chloroform $(10 \mathrm{~mL})$ in a round bottom flask. The solvent was removed by reduced pressure evaporation to produce a thin film on the interior of the flask. Phosphate buffer saline (PBS, $10 \mathrm{~mL}$ ) was then added, and the film was dispersed by sonication (50 Hz, $5 \mathrm{~min}$ ). All the procedures were carried out under sterile conditions. Male Swiss mice (20-30 g), from the Oswaldo Cruz Foundation colony were lodged in a room with controlled temperature $\left(23 \pm 2^{\circ} \mathrm{C}\right)$ and lighting (lights on from 7:00 to 19:00 h), with free access to lab chow and tap water. The following substances were used for the whole pharmacological assay: Evans blue (Merck, Germany), lipopolyssacharide from E. coli, serotype 055-B5 (LPS), zymosan A, RPMI medium, phyto-hemaglutinin, sulphanilamide, naphthylenediamine, Trypan Blue (Sigma, USA), fetal bovine serum (Hyclone, USA) and $\left[{ }^{3} \mathrm{H}\right]$ thymidine (Amersham, Netherlands).

\section{Toxicity assessment}

Male Swiss mice (20-25 g) received per oral (p.o.) the hydrodistillate $\left(200 \mathrm{mg} \mathrm{kg}^{-1}\right)$ and an equivalent dose of vehicle was administrated to the control group. Both test and control groups (6 animals each) were observed for 24 $\mathrm{h}$ under normal environmental conditions, with free access to food and water.

\section{Anti-inflammatory evaluation}

Pleurisy was induced by the technique of Spector ${ }^{14}$ as modified for mice by Henriques et al. ${ }^{15}$. An adapted needle (13 x 5 gauge) was inserted carefully $1 \mathrm{~mm}$ through the right side of the thoracic cavity of mice to permit the injection of LPS (12.5 ng/cavity) in a volume of $100 \mathrm{~mL}$. Control animals received an equal volume of sterile saline. The animals were killed by $\mathrm{CO}_{2}$ inhalation, $24 \mathrm{~h}$ after the injection. Their thoracic cavities were washed with $1 \mathrm{~mL}$ of PBS containing heparin (20 $\left.\mathrm{IU} \mathrm{mL}^{-1}\right)$ and the fluid lavage collected for assessment of leukocyte accumulation. The pleural lavage fluid collected was diluted 40 times in Turk's solution and total leukocyte counts were made in Neubauer chambers under light microscopy. Differential leukocyte counts were determined in cytocentrifuged smears stained with May-Grünwald-Giemsa dye using an oil immersion objective $(100 \mathrm{x})$. The statistical significance $(\mathrm{p}<0.05)$ was analyzed by ANOVA followed by the Student Newuman Keuls test. Results were expressed as mean \pm S.M. 


\section{Acknowledgements}

The authors thank FAPERJ for the fellowships to M. F. S. Ramos.

\section{References}

1. Allan, R.D.; Correl, R.L.; Wells, R.J. Tetrahedron Lett. 1969, 4669.

2. Allan, R.D.; Correl, R.L.; Wells, R.J. Tetrahedron Lett. 1969, 4673.

3. Proksch, P.; Rodriguez, E. Phytochemistry 1983, 22, 2335.

4. Allan, R.D.; Wells, R.J.; Macleod, J.K. Tetrahedron Lett. 1970, 3945.

5. Allan, R.D.; Wells, R.J.; Macleod, J.K. Tetrahedron Lett. 1973, 3.

6. Dorsch, W.; Wagner, H.; Neszmelyi, A.; Stuppner, H. Arch. Allergy Immunol. 1992, 99, 493.

7. Dorsch, W.; Müller, A.; Christoffel, V.; Stuppner, H.; Antus, S.; Gottsegen, A.; Wagner, H. Phytomedicine 1994, $1,47$.
8. Adams, R. P. Identification of Essential Oil Components by Gas Chromatography / Mass Spectrometry. Allured Publishing Corporation, Illinois, USA, 1995, 470 pp.

9. Morimoto, M.; Fujii, Y.; Komai, K. Phytochemistry 1999, 51, 605.

10. Jain, A.C.; Zutshi, M.K. Tetrahedron 1972, 28, 5589.

11. Yamaguchi, S.; Takai, M.; Hanazome, I.; Okada, Y.; Kawase, Y. Bull. Chem. Soc. Jpn. 1987, 60, 3603.

12. Croasmun, W.R.; Carlson, R.M.K. Eds.; Two-Dimensional NMR Spectroscopy; VCH, New York, 1994, and references cited therein.

13. Braun, S.; Kalinowski, H.O.; Berger, S. 100 and More Basic NMR Experiments; VCH, Weinheim, 1996, and references cited therein.

14. Spector, W.G. J. Pathol. Bacteriol. 1956, 72, 367.

15. Henriques, M. G.M.O.; Weg, V.B.; Martins, M.A.; Silva, P.M.R.; Fernandes, P.D.; Cordeiro, R.S.B.; Vargaftig, B.B. Br. J. Pharmacol. 1990, 99, 164.

Received: November 14, 2000 Published on the web: May 16, 2001 